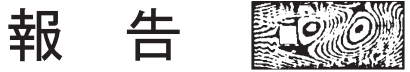

\section{第 6 回日中韓風工学に関する国際ワークショップ開催報告 \\ Report of the 6th China-Japan-Korea International Workshop on Wind Engineering (CJK2017)}

勝地 弘*

Hiroshi KATSUCHI

第 6 回日中韓風工学に関する国際ワークショップ（日 韓でのワークショップ時代からでは通算 12 回目) が, 2017 年 10 月 13，14 日の 2 日間にわたって，山梨県富士 吉田市の富士急ハイランドホテルにおいて開催された (写真 1)。持ち回りにより, 今年は日本の開催となり, 日本風工学会が担当した。1 日目は, 会場の富士急ハイラ ンドホテルにおいて研究発表と懇親会が実施され, 2 日目 は，スタディツアーとして，(株）風工学研究所の風洞実 駼施設および富士山五合目を訪問した。

このワークショップは, 2005 年より日本風工学会と韓 国風工学会が毎年, 持ち回りで開催してきた日韓風工学 会議（JaWEiK）に 2012 年より中国が加わり, 新たに日 中韓風工学に関する国際ワークショップ (CJK) として
スタートしたものである。中国から 13 名, 韓国から 11 名, 日本から 14 名の合計 38 名の参加者があった。

1 日目の開会式では, 日本風工学会の野村卓史会長 (日 本大学) から挨拶を行った (写真 2 )。その後, 18 編（中 国 8, 韓国 6, 日本 4) の研究発表が 4 つのセッションに 分かれてあった。

研究発表終了後は, 同じホテル内で懇親会が開催され, 意見交換，情報交換を行いながら笮親を深めた。特に， 韓国からは若い研究者が数名参加しており，とてもいい 刺激となったとの感想を得た。

2 日目は，貸切バスを利用して，（株）風工学研究所の 風洞実験施設『風のアトリエ』と富士山五合目を訪問す るスタディツアーを実施した。風のアトリエでは, 風観

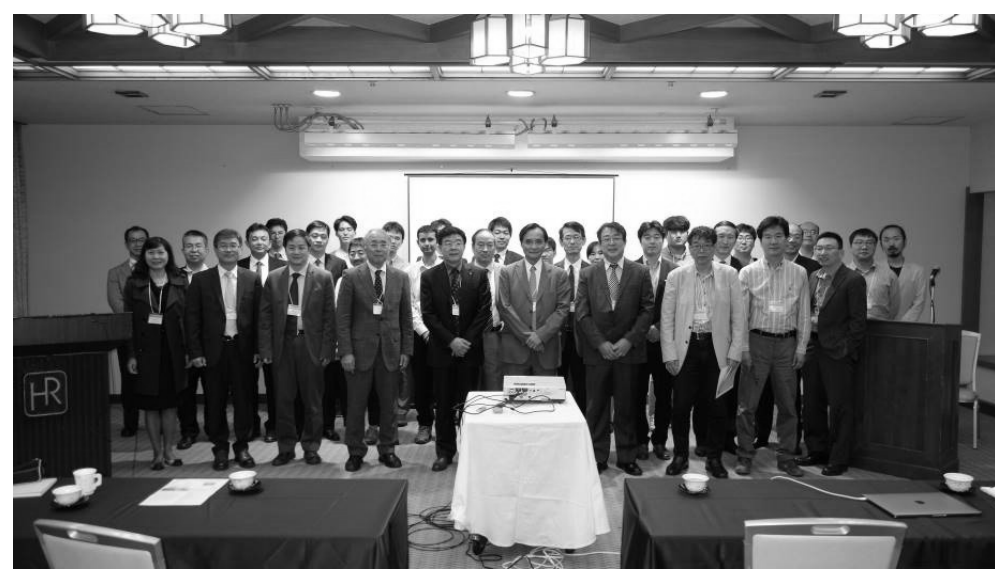

写真 1 CJK2017 の参加者

* 横浜国立大学大学院都市イノベーション研究院 教授

Professor, Faculty of Urban Innovation, Yokohama National University 


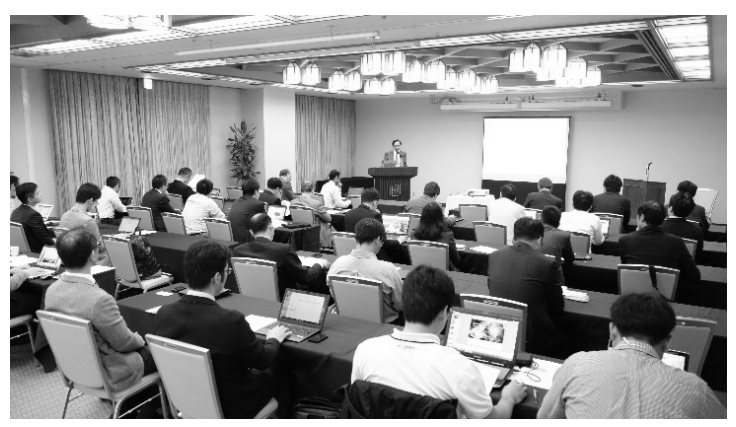

写真 2 開会式で挨拶する野村会長

測業務や風洞実験について説明を受け，熱心な質疑応答 がなされた。さらに，午後は富士山五合目を訪問し，秋 を迎えた高地の雰囲気を楽しんだ（写真3）。また，わず かな時間であったが富士山の山頂も間近に見え，海外か らの参加者に満足いただけたようである。

来年は韓国での開催となるが, 6 月のソウルで開催予定

の CWE の機会に合わせての開催を予定しているとのこ とであった。詳細は, 今後, 学会誌等で案内したい。

最後に, 準備, 実施にあたり, (株) 風工学研究所の皆 様にご協力をいただきましたことに感謝申し上げます。

テクニカルセッションプログラム

\section{Session 1: Bridges}

1) Prediction of critical flutter speed of streamline box girders using flutter factors, Qi Wang (Southwest Jiaotong University)

2) A preliminary experimental investigation of post critical flutter behaviors of suspension bridges, Xugang Hua (Hunan University)

3) The effect of lock-in range on OMA-based damping estimation for long-span bridges, Sunjoong Kim, Ho-Kyung Kim (Seoul National University)

4) Effects of errors in aeroelastic coefficients on buffeting response of cable-supported bridges, Dong-Woo Seo (Korea Institute of Civil Engineering and Building Technology), Sungsu Lee (Chungbuk National University)

\section{Session 2: Natural hazards and energy}

5) (5) Distribution characteristics of downburst wind loading in China, Honghai Li (China Academy of Building Research)

6) Development of Probabilistic Risk Assessment for Natural Hazards, Wooseok Yun, Hee-Jung Ham, Seung Hun Choi (Kangwon National University), Sungsu Lee (Chungbuk National University)

7) Wind speed forecast by using numerical weather

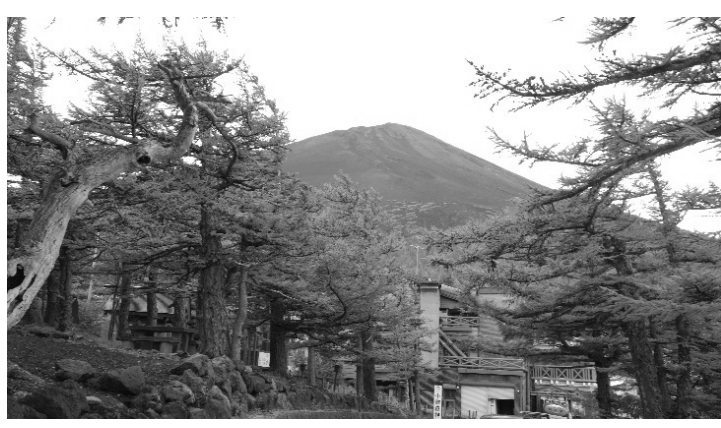

写真3 スタディツアー（富士山五合目）

prediction and on-site measurement, Atsushi Yamaguchi (University of Tokyo)

8) A framework for simulation and optimization of energy extraction in wind farms, Jay Parakash Goit (University of Tokyo)

\section{Session 3: Buildings and structures}

9) Investigation on peak factor of across-wind dynamic response of high-rise building by wind tunnel test, Shuguo Liang (Wuhan University)

10) High performance computation by BCM-LES on flow and pressure field around actual urban area and buildings, Hidenori Kawai (Tokyo Institute of Technology)

11) The Overshoot of Aerodynamic Force on Gable Roof Body under Step-function-like Gusty Wind, Kazuhiro Otsubo (Wind Engineering Institute)

12) Model-selection uncertainty quantifications in HFFB dynamic analyses of a complex tall building, Mingfeng Huang (Zhejiang University)

13) A novel unified wind-induced interference criteria based on the reinforcement envelope of cooling towers, Lin Zhao (Tongji University)

\section{Session 4: Cables and others}

14) Cable surface roughness and distortion effect on aerodynamic forces and vibration, Qingkuan Liu (Shijiazhuang Tiedao University)

15) Suppression of wake-induced galloping of stay cables using connectors in wind tunnel, Xuhui He (Central South University)

16) Estimation for peak fluctuating tensile force in multiple electrical transmission line, Jongkook Hwang (Korea National University of Cultural Heritage)

17) Numerical Analysis of Effect of Rotational Flexible wing on Aerodynamic Performance of the Flapping Micro Aerial Vehicles in Hovering Flight, Sanghoon Yoon (Seoul National University)

18) A vision-based direct measurement of displacements in vibrating systems, Seung-Hoon Shin, Hongjin Kim (Kyungpook National University) 